\title{
Economic Analysis of Fisheries Sector of Sindh, Pakistan: Current Status and Future Potential
}

\author{
${ }^{1}$ Muhammad Noman, ${ }^{1}$ Yongtong Mu*, ${ }^{1}$ Muhammad Mohsin, ${ }^{2}$ Zainab Hamid, \\ ${ }^{1}$ Muhammad Talib Kalhoro, ${ }^{1}$ Syed Babar Hussain Shah \\ ${ }^{1}$ College of Fisheries, Ocean University of China, Qingdao, 266003, China \\ ${ }^{2}$ Department of Zoology, University of Gujrat, Gujrat, 50700, Pakistan
}

*Corresponding Author: Yongtong Mu, College of Fisheries, Ocean University of China, Qingdao, 266003, China

\begin{abstract}
Sindh is endowed with an immense variety of fisheries resources. It has a coastal belt of $352 \mathrm{~km}$ which holds $71 \%$ of fisheries resources of Pakistan. This study reveals that the contribution of this coastline is $66 \%$ of total marine capture fisheries production in Pakistan. However, a number of constraints such as mismanagement, lack of enforcement of environmental laws, overexploitation, degradation of marine fisheries resources, poor handling techniques, practice of traditional gears, pollution, ineffective marketing system and remoteness to market hinder the growth of fisheries sector in the region. The Government should take a keen interest in the sustainability of the fisheries sector. Emphasis should be given to boost fish production, increase in export earnings, strengthen the fisheries infrastructure, increase local consumption of fish, modification of fishing effort, wise utilization of untapped resources and especially, improving the socioeconomic state of the fishing communities.
\end{abstract}

Keywords: Fisheries Sector, Production, Commercial Fish Groups, Fishing Crafts, Sindh, Pakistan

\section{INTRODUCTION}

Fishing is one of the most vital activities along Sindh's coastline [1]. This coastline is $352 \mathrm{Km}$ and contains $71 \%$ of Pakistan's fisheries resources. The coastal waters are well-matched for fisheries production by means of the accurate salinity and temperature characteristics [2]. This coastline is an extremely productive area endowed with a great biodiversity due to the combination of riverine flow into the Indus delta and sub-tropical environment [3]. Furthermore, recent assessments shows that $70 \%$ of the total marine resource production for Pakistan came from this coastline [4].

The fishery is a significant contributor to agricultural economy of Pakistan. Pakistan's fisheries sector started from scratches and the marine fish catch was only 33,000 $t$ at the time of independence (1947). This catch was carried out in hand-driven traditional boats. Recently, the annual marine catch reaches up to 500,000 $\mathrm{t}_{\text {year }}{ }^{-1}$ and carried out through mostly motorized fishing vessels which are operated from four fish harbors and nine landing jetties situated in Sindh and Balochistan [5]. However, Karachi fish harbor is the biggest of all and handles over $80 \%$ of industrial fishing fleets. Thus, Sindh coastline plays significant role in the total marine catch of the country [1].

Pakistan is gifted with a wide variety of fisheries resources including 150 commercially important species [1]. Most valued species are exported, while a major part of the total catch is converted into fishmeal for export, as well as for use in the local poultry as feed. The main export species include shrimp, Indian mackerel, ribbon-fish, tuna, sole, and crab. Pakistan exported US $\$ 394.217$ million of fisheries products to the global markets during the last fiscal year 2017 higher by $21.35 \%$ or US\$69.348 million as compared to the seafood export of US\$324.869 million in the fiscal year 2016 [6].

Fisheries sector contributes significantly to the economy of Pakistan and is considered to be a source of livelihoods for the coastal communities [7]. The share of fisheries sub-sector in agriculture and national gross domestic production (GDP) was $2.1 \%$ and $1 \%$ respectively during the fiscal year 20142015 [8]. Although the influence of the fisheries sector on GDP is very low but this sector provides 
direct employment to 400,000 people and another 600,000 are engaged with associated industry [2]. Therefore, fisheries sector is supposed to be a salient contributor to the economy of Sindh in general and Pakistan in particular.

The aim of this study is to describe the contribution of Sindh fisheries sector in the economy of Pakistan. Furthermore, in the present study, an attempt has been made to document some serious problems facing this sector and also indicates the future investment opportunities in Sindh. Hence, this work will be helpful to grab the attention of the government towards the solution of these issues and will also increase the concern of the stakeholders in further investment opportunities.

\section{Material AND Method}

The objectives of this study have been achieved through a broad review of literature related to Sind fisheries sector. In addition to this, a lot of information is gathered through the extensive study of published research articles, reports, opinion articles, communications and newspaper articles. The government officials were also contacted to obtain maximum information. The private stakeholders were also involved to explore and analyze the real current position and future potential of this sector in this region. The published data of Sindh fisheries sector were obtained from the Development Statistics of Sindh printed by Bureau of Statistics, Govt. of Sindh Karachi in order to gain full insight into project objectives. Microsoft Word Excel 2010 was used to represent numbers into the graphical form. Same software also served to calculate percentages and annual growth rates. Annual growth rates were calculated as GR $=($ Present V - Past V) / Past V. In this expression V represents value.

\section{Results}

The reported production of fisheries along the coastal belt of Sindh was totaled as 2,989,700 $t$ during 2001 to 2013. The highest and the lowest production was recorded as $286,800 \mathrm{t}(2002)$ and $196,600 \mathrm{t}$ (2013), respectively. The average capture production during this period remained as 229,980 t year ${ }^{-1}$. Fig. 1 reveals that the capture production was first increased from 278,500 t (2001) to 286,800 t (2002) with the growth rate of $0.02 \%$. Afterward, the capture production showed decreasing trend until 2007 (205,300 t). Whereas, in the next year (2008), the capture production increased to 223,000 t with the growth rate of $0.08 \%$. But, once again the capture production was decreased and reached to the lowest value of $196,600 \mathrm{t}$ in 2013 . The capture production throughout study period (2001-2013) along the coastal belt of Sindh is highlighted in Fig. 1.

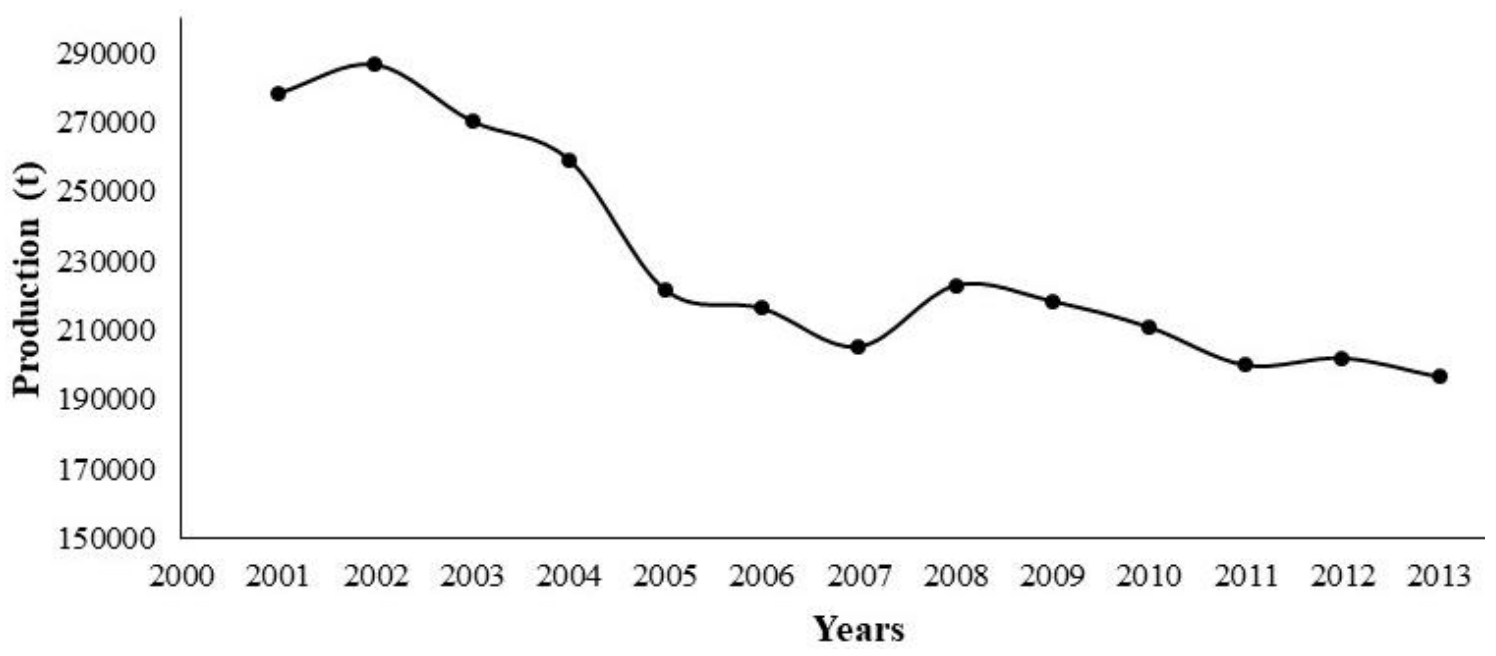

Figure1. Total marine capture production from Sindh (2001-2013)

There are almost twenty-four major commercial fish groups which are landed on the harbor stations along the entire coastline of Sindh. Fig. 2 represents that out of these major commercial fish groups, only ten groups, viz. catfishes, croaker, small groupers, poplet (white and black), queen fish, mullets, sardinella, surmai, sharks and rays, account for almost $40 \%(113,5943 \mathrm{t})$ of total commercial catch $(2,989,700 \mathrm{t})$. The total commercial catch of all major commercial groups except poplet and surmai showed decreasing trend throughout study period. The total commercial catch of poplet with some fluctuations almost remained same i.e. 3,776 t (2001) to 3,762 t (2013). On the other hand, the total 
commercial catch of surmai increased from 2,917 t (2001) to 4,189 t (2013). The overall capture production of all commercially important fish groups and their share in terms of percentage throughout study period is highlighted in Fig. 2 and 3, respectively.

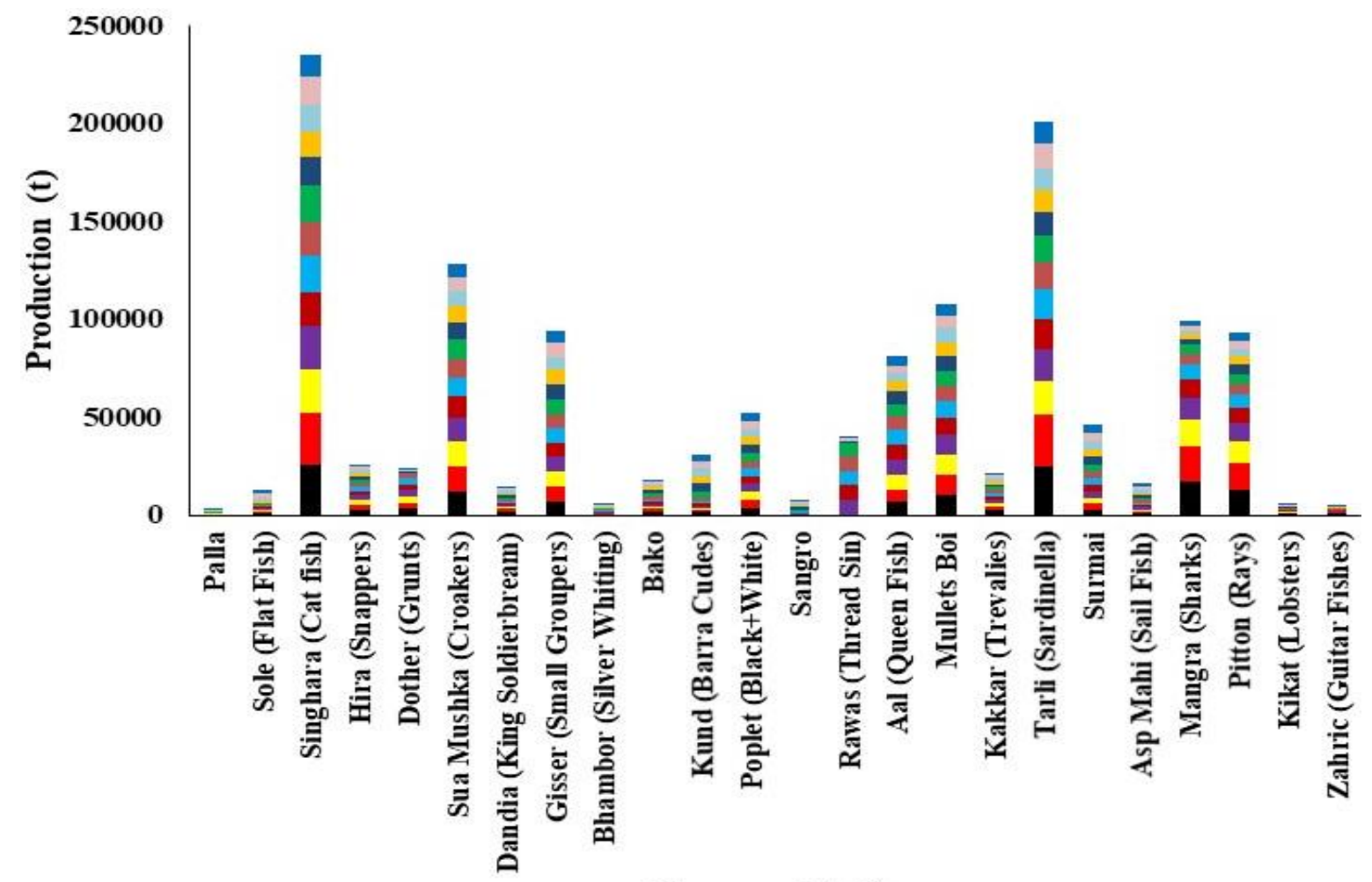

\section{Commercial Groups}

-2001 $=2002=2003=2004=2005=2006=2007=2008=2009=2010=2011=2012=2013$

Figure2. Production of commercially important fisheries groups from Sindh (2001 to 2013)

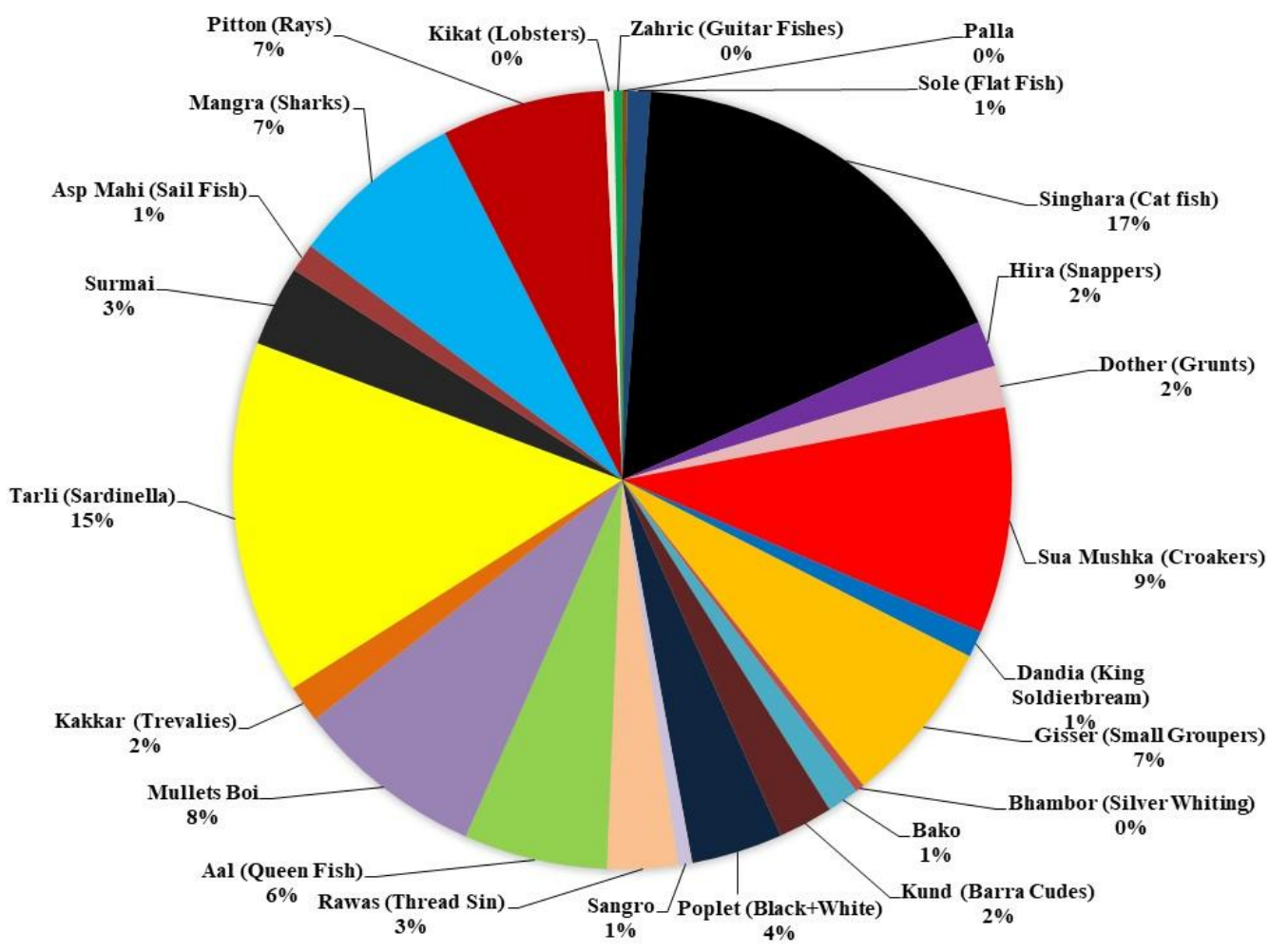

Figure3. Contribution of commercially important fisheries groups in total marine capture production (20012013) 
Fishing is carried out throughout Sindh coastline with the use of four kinds of fishing vessels viz. trawlers, gill netters, mechanized cum sail boats and sail boats. The number of trawlers and gillnetters first increased from 2,578 (2001) to 3,010 (2010) and 2,327 to 2,670 (2010) respectively. But, their number showed sharp decreasing trend in the next year (2011) to 2,094 and 1,295 correspondingly. Finally, with the slight increase it reached up to 2,336 (trawlers) and 1,423 (gill netters) in 2013. The mechanized cum sail boats increased throughout study period from 3,928 (2001) to 4,968 (2013). On the other hand, the recorded data of sail boats was only available up to 2010. The overall number of sail boats decreased from 6,509 (2001) to 6,404 (2010). The year-wise data of different types of fishing vessels along Sindh coast is presented in table 1.

Table1. Total fishing vessels in Sindh: 2001-2013

\begin{tabular}{|l|l|l|l|l|l|l|l|l|l|l|l|l|l|}
\hline & $\mathbf{2 0 0 1}$ & $\mathbf{2 0 0 2}$ & $\mathbf{2 0 0 3}$ & $\mathbf{2 0 0 4}$ & $\mathbf{2 0 0 5}$ & $\mathbf{2 0 0 6}$ & $\mathbf{2 0 0 7}$ & $\mathbf{2 0 0 8}$ & $\mathbf{2 0 0 9}$ & $\mathbf{2 0 1 0}$ & $\mathbf{2 0 1 1}$ & $\mathbf{2 0 1 2}$ & $\mathbf{2 0 1 3}$ \\
\hline Trawlers & 2578 & 2599 & 2702 & 2800 & 2815 & 2830 & 2920 & 2955 & 2966 & 2010 & 2094 & 2112 & 2336 \\
\hline $\begin{array}{l}\text { Gill } \\
\text { Netters }\end{array}$ & 2327 & 2398 & 2510 & 2550 & 2555 & 2560 & 2612 & 2648 & 2648 & 2670 & 1295 & 1366 & 1423 \\
\hline $\begin{array}{l}\text { Mechani } \\
\text { zed Cum } \\
\text { Sail } \\
\text { Boats }\end{array}$ & 3928 & 3966 & 4388 & 4400 & 4430 & 4440 & 4482 & 4532 & 4538 & 4560 & 4784 & 4863 & 4968 \\
\hline $\begin{array}{l}\text { Sail } \\
\text { Boats }\end{array}$ & 6509 & 6555 & 6809 & 6200 & 6210 & 6240 & 6310 & 6386 & 6395 & 6404 & --- & --- & -- \\
\hline
\end{tabular}

\section{DISCUSSION}

Fisheries sector plays a very important role in the socio-economic development of the country. The importance of this sector is also accepted to stimulate the development of a number of subsidiary industries. Thus, this sector is considered as powerful income and employment generator at local and national level. Similarly, as compared to other agricultural commodities, fish export is a foremost contributor to foreign exchange earnings in many countries [9]. Besides being a foreign exchange earner, it is also a source of inexpensive and nutritive food. Moreover, marine fisheries resources are also considerably contributing to foreign exchange revenue through licensing fees of foreign fishing fleets. Most importantly, it is the source of livelihood for a large section of the economically backward population of the country [10].

Fisheries sector contributes significantly to the economy of Pakistan and is considered to be a source of food and livelihood for coastal communities [11]. The share of this sector in GDP of the country is only $1 \%$ and total (marine + inland) fish production was estimated 501,000 $\mathrm{t}$ during the fiscal year 2015-2016. The share of marine and inland in total production was $73.45 \%(368,000 \mathrm{t})$ and $26.55 \%$ $(133,000 \mathrm{t})$, respectively [12]. Moreover, about 0.4 million people are directly attached to fishing while almost 0.6 million works down the line of its value-chain, thus making it $1 \%$ of the labor force of the country [5]. However, Karachi Fish Harbour is the main hub of fishing activity in the country. It is assessed that more than $60 \%$ of the fishing fleet is based in Karachi Harbour whereas, about $20 \%$ of the fleet is based in Ibrahim Hyderi and adjacent area. Thus, a total of about $80 \%$ of the fishing fleet is based in and around Karachi (Sindh) [1]. Consequently, Sindh's fisheries sector play a significant role in the improvement of the socio-economic status of coastal communities by providing them food and livelihoods.

Similarly, the fishery industry is also contributing to the national economy of Pakistan as a major source of foreign exchange earnings. Pakistan has a local and an international market for fish, shrimps and fish products. At the domestic level, the catch from marine fisheries is supplied to the local fish markets; frozen or processed fish is supplied to only a few large departmental stores in some cities [13]. On an international level, Pakistan has a respectable market for fish and fish products. About $30 \%$ to $40 \%$ of the total fish catch is exported to 30 countries of the world. Pakistan's exports of fish and fish products were totaled as 91,965 t during the fiscal year 2015-2016. China, Thailand, Malaysia, Sri Lanka, Middle East, Japan, etc. are the major buyers of Pakistan's fish and fish products and Pakistan earned US\$240.108 million [12]. Our findings show that the contribution of the total marine catch from Sindh coastline is about $66 \%$ of the total catch of Pakistan. So, it is very clear that 
commercial fish production from Sindh coast shares significantly in total national production and export earnings.

Although, Sindh fisheries sector contribute significantly to the economy of Pakistan but this sector still faces numerous constraints which restrict its growth. Moreover, the future investment opportunities still exist to attract the intention of stakeholders in order to uplift the fisheries sector in the region. These issues and future investment opportunities are discussed in the following section of this article.

\subsection{Issues and Suggestions}

The federal and provincial governments take a number of initiatives for the development of fisheries sector in the country. Nevertheless, influential steps are required to solve the following issues for the betterment of Sindh's fisheries sector:

1) Present regulatory framework, policy, and legislation are archaic and insufficient for the management of the modern fishery. Thus, a detailed review, amendments, and revisions to recent Act and policies are required to sustain progressive improvement of marine capture fisheries.

2) Overfishing is the most critical issue facing marine capture fisheries in Sindh and fact is that this is not extensively understood and addressed.

3) Illegal, unregistered and unreported (IUU) fishing and the contract fishing system are harmfully affecting the resources on which the fishery depends. Hence, better monitoring control and surveillance are required to decrease illegitimate and negative methods being used, and control poaching from Sindh and Iran.

4) Pollution and habitat destruction (i.e. mangroves clearance) are leading to decrease in productivity of fisheries sector which in turn will adversely affect the financial health of the fisheries sector. Hence, there is a need to proper enforcement of the existing laws for the protection and conservation of the environment.

5) According to FAO, 30 to $40 \%$ of the total catch is lost due to poor post-harvest practices. So, there is need to develop post-harvest facilities i.e. jetties, chilling plants, landing plate forms, processing plants, cold storages, auction halls/ markets and marketing channels including transportation.

6) The Fish stocks are depleting very fast due to overexploitation and merciless catching of fish seed through ban nets viz. Katra, Bullo and Gujjo, in Sindh. Thus, amendments are necessary for the existing rules to ban such illegal use of ban nets which adversely affect the socio-economic condition of coastal communities.

7) Pakistan is blessed with immense marine resources, but unfortunately, no wide-ranging data collection system has been established to update management. Therefore, the implementation of comprehensive and harmonized data collection and analysis systems across provinces coordinated by Fisheries Departments at Provincial/Areas level, with reporting to the Federal Bureau of Statistics (FBS) Pakistan, is required to increase the reliability of fisheries statistical data country-wide.

8) The improvement of existing infrastructure and investments in new infrastructure are required at landing sites.

\subsection{Future Investment Opportunities}

The main objective of development of fisheries sector is to improve the socio-economic condition of coastal communities. This goal is achieved through the optimization of financial benefits that can be gained from sound financial investment for the community up to a national development level. Thus, some investment opportunities in fisheries sector of Sindh are highlighted here to grab the attention of public-private investors.

1) A massive opportunity is present for infrastructure development as being the part of environmental impact assessment, master planning and surveys along coastal regions. These activities can be carried out through public-private joint ventures in order to gain mutual benefits.

2) Although, there is significant inland aquaculture is present in Sindh but the mariculture is still not practicing seriously along the Sindh coastline. So, mariculture (pen and cage culture) of highly 
profitable production of commercially important groups viz. sea bass, groupers, mullets, shrimps, crabs, and shellfish can be practiced along the coast of Sindh.

3) Shrimp farming is well-thought-out across the world to be highly profitable venture but commercial shrimp farming has not been able to gain the position in Sindh. Garho Farm at Thatta demonstrated the potential for such farming but only for a brief time. However, a model shrimp farm i.e. Reliance Aqua Farm, recently, has established by a private invester. Therefore, shrimp farming along the coastal belt of Sindh is the wave of the future and promises great returns on investment.

4) Great potential exists in the form of untapped niche markets like that of mud crab, blue swimmer crab, jellyfish, other shellfish, and fish oils in Sindh. Such farming is best suited for mariculture activities.

5) For further value addition, seafood processing plants can be built near the coastal belt of Sindh as on the pattern of successful Mahi Foods Company.

6) Recently, there is no feed mill is present along throughout Sindh coast for making shrimp and fish feed. Thus, the market infrastructure on commercial basis can be enhanced by establishing of further feed mills and hatcheries.

7) Flake ice plants are also needed for improving post-harvest management of fisheries resources of Sindh. As a latest alternative of ordinary ice, flake ice does not stick into the flesh of fish and shrimps and also preserves the eminence of seafood. This is a very profitable venue for investment, especially near the coastal areas.

8) Environmentally sound tourism-related facilities can also be established along the coastal belt of Sindh in order to earn great revenue. Similarly, there is need to preserve and promote sites of archaeological interest and value along the coast.

\section{CONCLUSION}

Pakistan is blessed with a wealth of fishery resources. These resources play a significant role in the economy of Pakistan in providing highly nutritious animal protein, income and employment generation, and foreign exchange earnings. Nevertheless, these resources are not being fully used according to their potential which results in the under-developed fishery industry. The major constraints are lack of institutional facilities, shortage of fish seed of cultural species, lack of basic knowledge of fish farm and capital to run new ventures. Despite sufficient production as well as export potential, the Pakistan's fisheries sector has not been able to attain a satisfactory growth rate. There is need to emphasize on the boost of fish production, increase in export earnings, strengthen the fisheries infrastructure, increase local consumption of fish, modification of fishing effort, wise utilization of untapped resources and especially, improving the socio-economic state of the fishing communities.

\section{ACKNOWLEDGEMENT}

The first author is grateful to Chinese Scholarship Council (CSC) for funding his Ph.D. Degree. This work is supported by the special research fund of China Agriculture Research System (CARS-49).

\section{REFERENCES}

[1] WWF, Study on value added to the catch of fisher folk (fisheries development for sustainable livelihood. Final report, World Wide Fund for nature Karachi, Pakistan, July 2005, Pp. 1-35 (2005). Retrieved from http://www.wwf.org.pk/pdf/tp_sp_fishereies_report.pdf.

[2] SBI. Sindh-The land of opportunities: Fisheries. Sindh Board of Investment, Govt. of Sindh, 1st Floor, Block B, Finance and Trade Center, Shahra-e-Faisal, Krachi, Pakistan. Retrieved from http://sedf.gos.pk/pdf/sectors/fishries.pdf.

[3] ADB, To the Islamic Republic of Pakistan for preparing the Sindh coastal and inland community development project. Technical Assistance (Financed by the Japan Special Fund). TAR: PAK 37188, Asian Development Bank, Pp. 1-14 (2004). Retrieved from https://www.adb.org/sites/default/files/projectdocument/69535/tar-pak-37188.pdf

[4] ADB, Proposed Loan Islamic Republic of Pakistan: Sindh Coastal Community Development Project. Project Number: 37188, Asian Development Bank, Pp. 1-60 (2006). Retrieved from https://www.adb.org/sites/default/files/project-document/66558/37188-pak-rrp.pdf. 
[5] Dawn, Overexploitation of fisheries resources. February, 13, 2017. Retrieved from https://www.dawn.com/ news/1314445.

[6] Business Recorder, Fishing season begins today: fishermen hope seafood export may go up. July, $31^{\text {st }}$, 2017. Retrieved from http://fp.brecorder.com/2017/07/20170731203607/.

[7] Mohsin, M., Mu, Y., Memon, A.M., Kalhoro, M.T., Shah, S.B.H., Fishery stock assessment of Kiddi shrimp (Parapenaeopsis stylifera) in the Northern Arabian Sea Coast of Pakistan by using surplus production models. Chinese J. Oceanol. Limnol. (2016):1-11.

[8] GoP, Economic Survey of Pakistan 2014-2015, Ministry of Finance, Gov. of Pakistan. p. 42 (2015). Retrieved from: http://121.52.153.178:8080/xmlui/handle/123456789/13877.

[9] Fisheries and Economic Development. Retrieved from http://nptel.ac.in/courses/120108002/module6/ lecture15.pdf.

[10] Finegold, C., The importance of fisheries and aquaculture to development. America, 1990(1980), p. 1970 (2009). Retrieved from http://pubs.iclarm.net/resource_centre/WF_2546.pdf.

[11] Mohsin, M., Mu, Y., Hussain, K., Memon, A.M., Zhaoqun, Nazir, K., and Wei, W., Contribution of fish production and trade to the economy of Pakistan. Int. J. Mar. Sci., 5(18): 1-7 (2015).

[12] GoP, Economic Survey of Pakistan 2015-2016, Ministry of Finance, Gov. of Pakistan. p. 44 (2016). Retrieved from: http://121.52.153.178:8080/xmlui/handle/123456789/14893.

[13] Memon, N.A., Export of fish and fish products: China and Middle East are main markets. Pak. Food J. May-June: 30-31 (2012).

Citation: M. Yongtong, "Economic Analysis of fisheries Sector of Sindh, Pakistan: Current Status and Future Potential ", International Journal of Innovative Studies in Aquatic Biology and Fisheries, vol. 3, no. 2, p. 2329, 2017. http://dx.doi.org/10.20431/2454-7670.0302005

Copyright: () 2017 Authors. This is an open-access article distributed under the terms of the Creative Commons Attribution License, which permits unrestricted use, distribution, and reproduction in any medium, provided the original author and source are credited. 